Scientific journal

PHYSICAL AND MATHEMATICAL EDUCATION

Has been issued since 2013.

Науковий журнал

ФІЗИКО-МАТЕМАТИЧНА ОСВІТА

Видається з 2013.
ISSN 2413-158X (online)
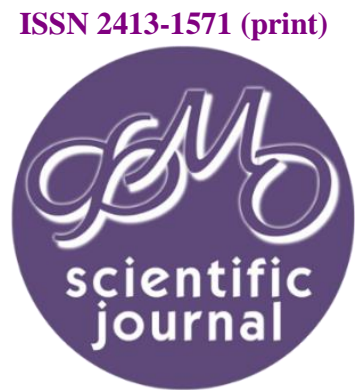

http://fmo-journal.fizmatsspu.sumy.ua/

Буров О.Ю. Профільне математичне навчання: особливості структури інтелекту старшокласників. Фізикоматематична освіта. 2018. Випуск 1(15). С. 108-112.

Burov O. Profile Mathematical Training: Particular Qualities Of Intellect Structure Of High School Students. Physical and Mathematical Education. 2018. Issue 1(15). P. 108-112.

UDC 37.376:159.92:004.9

Oleksandr Yu. Burov Institute of Information Technologies and Learning Tools of the NAPS of Ukraine, Ukraine ayb@iittt.gov.ua DOI 10.31110/2413-1571-2018-015-1-018

\title{
PROFILE MATHEMATICAL TRAINING: PARTICULAR QUALITIES OF INTELLECT STRUCTURE OF HIGH SCHOOL STUDENTS
}

Abstract. The article discusses development of the intellect's structural components in high school students of mathematical profile schools/classes in comparison with high school students generally (without accounting their profile orientation). The experiments included psychological tests performance by subjects at the computer, namely: modified $R$. Amthauer test of intellect structure, color-associated Lusher test (paired choice), Myers-Briggs Type Indicator. There were observed about 3800 schoolchildren of $7 . . .11$ academic years. The research results have confirmed the data on the steady growth of the level of intellect development with the predominant dominance of the verbal component in senior adolescence. At the same time, the differential analysis of individual components of intellect indicated the heterochronity of this process, with various accelerations in grades 10-11. It was revealed that such intellect components as search for common features, for similarity and analogy, mathematical calculation as well as revealing of regularities could be explained by the influence of specialized mathematical training. It was confirmed by the comparison analysis with averaged general schools data, where significant variation was revealed in all components of the intellect, as well as their lower level of development. Dynamic changes of the same students' group "intellect profile" over grades 9, 10 and 11 in all intellect components increased in the last year of schooling. It is proposed the index "development acceleration index" (DAl) to analyze and to compare such changes. The DAl analysis allowed that increase of the intellect components in grades 10 and 11 of the lyceum of math profile was not revealed, in contrast with general school tendency that was found in previous research. It can be assumed that selection of children with high math abilities and appropriate training in 8-th class ensured not only good math skills, but development of higher intelligence. In general, the results of research have clearly demonstrated that intellect of high school students had dynamic nature in micro-age intervals. Differences in its measurement (in this age) was not a result of insufficient retest validity, but a result of the intellect intensive development, and this should be taken into account in assessing the abilities of students and in their choice of future profession.

Key words: intelligence, measurement, experimentation, computer tools.

\section{The problem setting.}

The time changes everything very quickly and the rate of these changes increases. This trend generates new demands on the workforce and its preparation. Knowledge-based approach has been replaced by competency-based one. Key competences were defined and recognized at the international level, one of them is mathematics [1]. As a result, "Rapid economic, technological and social changes are creating a world that is ever more interconnected and interdependent. Globalization of economies, the digital revolution, mass migration, and the prospect of climate instability are triggering new concerns and demanding a new kind of graduate" [2]. And this process will accelerate in near future evoking the necessity of lifelong learning [3] to build successful career which needs the high personal intelligence [4].

Analysis of actual studies.

As the main background to solve the problem mentioned above, one can point to on-line learning with additional opportunities for mental development of schoolchildren [5] with regards to new opportunities for education and development in social networks [6]. The main features of the intelligence development are analyzed and described quite thoroughly and deeply $[7 ; 8]$, including from various positions of its use and meaning [9]. But not the intellect in general plays important role in education and successful work of a human, but its structure and dynamic nature should be taken into account as well [10; 11] with special attention to social dimension [12] and effect of education workload on schoolchildren mental and physical health and effectiveness [13]. Specific features of mathematically gifted children are important [14] to understand ways of intellect formation, but analysis of effect of math profile education in special schools/classes on the intellect structure can give us eful information for teachers. 
The article's goal is to compare development of intelligence structure of schoolchildren of math profile school/classes and general ones.

Presentation of the main material.

Experiments included psychological tests performance by subjects at the computer according to technique developed and validated for the professional selection. There were used tests as follows:

- Modified R. Amthauer test of intelligence structure, assessment skills in the areas of mental activity.

- Color-associated Lusher test (paired choice), assessment of stress levels, readiness to perform tests, the balance of psychological qualities.

- Myers-Briggs Type Indicator (MBTI).

There were observed 3596 schoolchildren of $7 \ldots 11$ academic years (K7 ... K11). According to method used, indices for every student ('primary' data) were measured and "secondary" marks were calculated.

The core test technique was R. Amthauer Intellectual Structure Test. The aim of testing consists in assessment of the level of development and structural peculiarities of intellect as well as attention and memory. 160 questions were grouped into 8 subtests:

1. LS - the logical selection.

2. GE - search for common features.

3. AN - search for similarity, analogy.

4. RA - mathematical calculation.

5. ZR - revealing of regularities.

6. FS - the choice of figures on the plane forming an integral figure from its fragments.

7. WU - tasks with cubes (tests spatial and constructive thinking).

8. ME - task for the ability to focus and memorize the learned words.

Calculation of testing results was made in such a way:

1. The number of correct answers in all subtests was counted. Each correct solution gave one point.

2. The index of verbal intellect development level shall be calculated ( $\mathrm{VI}$ - i.e. the one based on verbal notions), by summarizing of points achieved in subtests $1-3$ and 8 .

3. The level of nonverbal intellect development shall be calculated (NI) by means of summarizing of points achieved in subtests $4-7$

4. The integral index (II) of intellect development level shall be calculated by means of summarizing points achieved for each of 8 subtests and recalculated into recognized IQ scale.

Lusher test has been used to obtain such indices: the K.Shiposhi coefficient of vegetation (associated with the level of ergotropic tone, stress, readiness for energy expenditure), stress level and capability. Those indices served as markers for the reliability of test results.

In earlier research there were revealed individual-psychological peculiarities of transforming process of the intellectual qualities structure of gifted adolescents depending on age (micro-intervals: from K7 to K11), profile/"directions of differentiation" of learning (physical and mathematical, chemical and biological, humanitarian, economic, etc.) and gender aspects were revealed [16]. Results were obtained by screening method of observation of Natural sciences lyceum \# 145 students.

The highest level of general intelligence was recorded in the students of the physical and mathematical profile, whose level of general intellectual development was $70.44 \%$. They were characterized by a harmonic structure of intelligence, with a slight predominance of nonverbal intelligence (verbal intelligence $\mathrm{VI}=69.85 \%$, non-verbal intellect $\mathrm{NI}=71.78 \%$ ). In the structure of non-verbal intelligence more noticeable individual differences were found than in the structure of verbal intelligence. The higher indicators were obtained for memory parameters (85.3\%), as well as the level of general awareness $(72.2 \%)$, the ability to search analogies (75.1\%), the ability to operate mathematical regularity $(74.3 \%)$, spatial imagination, and combinatorial abilities (73.2\%).

Lyceum 145 had a long history of effective work with gifted children if the field of math and physics, as well as traditionally a high rating to choose children with high abilities. So the question "abilities or teaching ?" remained open. To answer it, we carried out investigation of the intellect development in another math profile school (Lyceum 157, Kyiv). As it was demonstrated, the level of intellect development differed as well in adolescents of math and general schools [15].

To investigate common and specific features of the adolescence intelligence they were compared micro-interval dynamics of the general intellect (Fig.1), as well as its verbal and nonverbal components (Fig. 2) according to all data observation (without geographical, gender and profile specific) and data obtained in schools of math profile. The above results confirm the well-known data on the steady growth of the level of development of intelligence with the advance of the verbal component in the senior adolescence. At the same time, the differential analysis of individual components of intelligence indicates the heterochronity of this process, with various accelerations in grades 10-11.

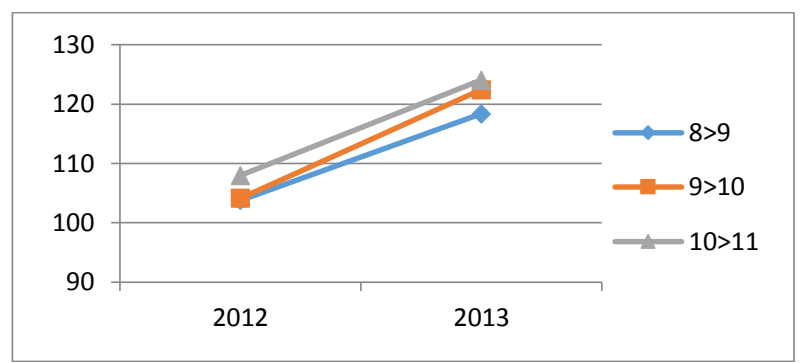

Fig.1. Average IQs of math profile students in two consequent years when they moved to the next class (from 8 to 9, from 9 to 10 and from 10 to 11) 
The screening method of survey gives general view on the static situation, but does not allow analyzing real changes in the intellect of students. To study such a dynamics, the analysis was provided in relation to monitor changes in intellect level of adolescences of the Lyceum 157 over two consequent school years. Namely, they were monitored results of intellect test performance of students K8 ... K11 in school years 2011-2012 and 2012-2013. Students of K8 in school year 2011-2012 moved to $\mathrm{K} 9, \mathrm{~K} 9$ to $\mathrm{K} 10$ and $\mathrm{K} 10$ to $\mathrm{K} 11$ respectively.

It follows from the graphs that the highest acceleration of the intellect development has been demonstrated by students of $\mathrm{K} 9$ in comparison with $\mathrm{K} 8$. This result does not correspondent previous research regards general tendency (the highest increase was revealed from $\mathrm{K} 8$ to $\mathrm{K} 9$ ). It can be assumed that selection children with high mathematical abilities and appropriate training in 8-th class ensure not only good math skills, but development of higher intelligence at earlier age than the average population.

To compare intellect structure of students of different age, they were compared components of the intellect for K8 ... K11. It was expected that all components in $\mathrm{K} 8$ are not higher than the older ones. But the attention was drawn to the fact that GE (search for common features) and FS (special thinking with objects on the plane) did not differ practically in all micro-interval groups (Fig.2). And components of GE, AN, RA and ZR increased after in K9 some level and did not differ in K9, K10 and K11.

One can draw a conclusion from this, that such structural components of the intellect as search for common features, search for similarity and analogy, mathematical calculation as well as revealing of regularities are results of development by math training. This is confirmed by the comparison analysis with the same diagram on general schools (Fig. 3), where significant variation was revealed in all components of the intellect, as well as their lower level of development.

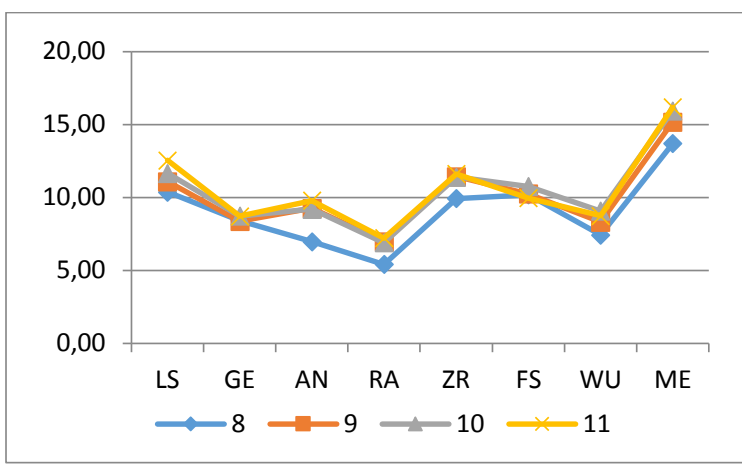

Fig. 2. Components of intellect of the Lyceum 157 students $K 8$... K11

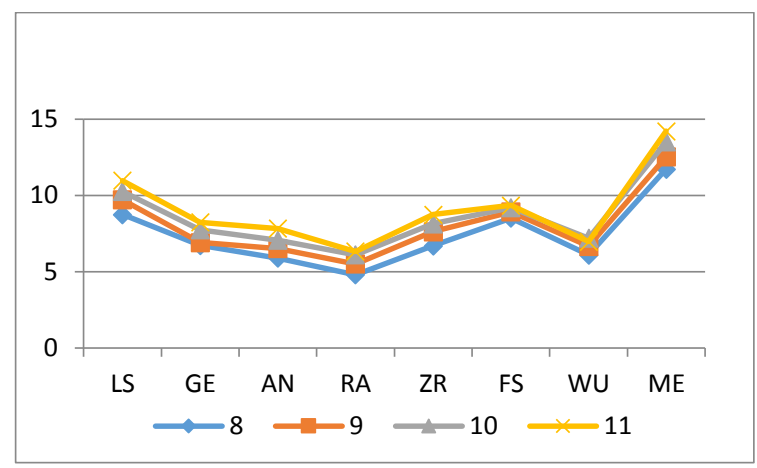

Fig. 3. Components of intellect of all schools students K8 ... K11

The screening method of survey gives general view on the static situation, but does not allowing analyzing real changes in the intellect structure of students. To study such a dynamics, the analysis was provided in relation to monitor changes in "intellect profile" of adolescence of the same school (school \#20 of linguistic profile with enhanced mathematical training) of consequent years of entering. Namely, results of intellect test performance of students K8 ... K11 were monitored in school years 2010-2011, 2011-2012 and 2012-2013.

As it can be seen from the figure, dynamic changes of the same students' group "intellect profile" (classes A, B, and C) over grades 9, 10 and 11 (Fig.4), all values of the intellect components increased in the last year of schooling. Some decreased indices in $\mathrm{K} 10$ in comparison with $\mathrm{K} 9$ could be explained by changes in persons of the classes when graduating K9 and some newcomers in K10. But screening of the same school in the year of graduating monitored group demonstrated different data [Fig.5]. Students of the new K9 (coming to this school two years later than monitored group) demonstrated higher results in subtests ZR and ME.

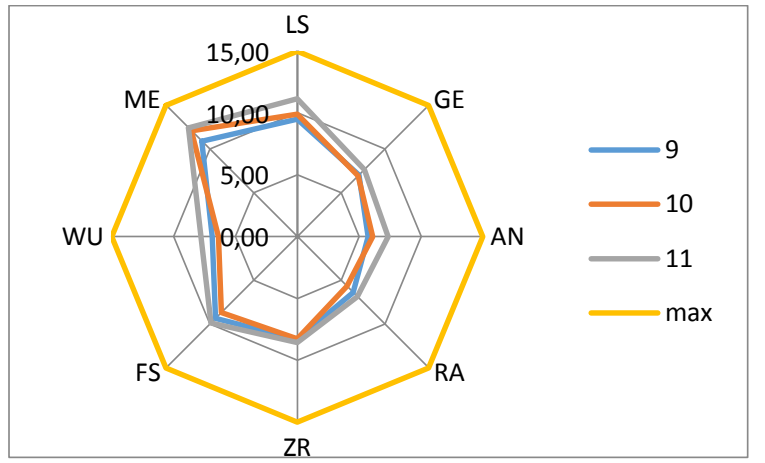

Fig. 4. Diagram of micro-age dynamics of intellect structure

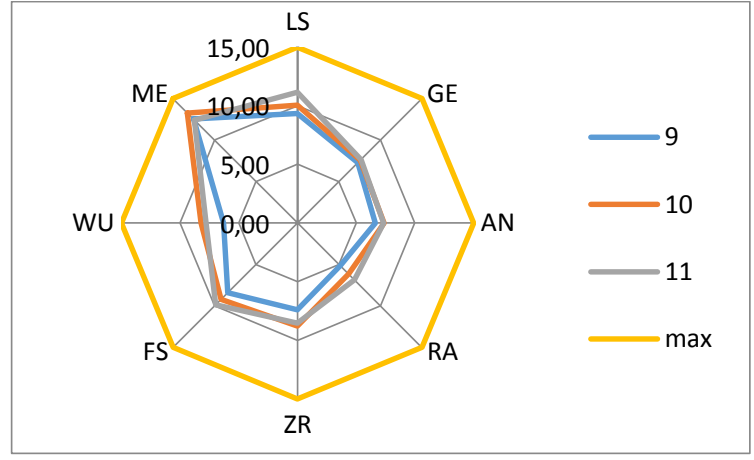

Fig. 5. Micro-age differences in intellect structure of the school 20

Comparison of transformation of the intellect components and their obvious heterochronicity draw attention to the question of the speed of such transformation in different constituents and in time. In order to evaluate the rate of changes of the level of components development, an "development acceleration index" (DAI) was proposed, which was calculated as the ratio of the level of development of the component $S i, i \ni\{\mathrm{LS}, \mathrm{GE}, \mathrm{AN}, \mathrm{RA}, \mathrm{ZR}, \mathrm{FS}, \mathrm{WU}, \mathrm{ME}\}$ on the micro-interval $\mathrm{k}(\mathrm{k}=[8,11])$ to its value on the interval $\mathrm{k}-1$. In other words, 


$$
\operatorname{DAI}_{\mathrm{i}}^{\mathrm{k}}=\frac{\mathrm{S}_{\mathrm{i}}^{\mathrm{k}}}{\mathrm{S}_{\mathrm{i}}^{\mathrm{k}-1}} .
$$

The results of calculations $\mathrm{DAI}_{\mathrm{i}}^{\mathrm{k}}$ are given in Table 1 and indicate an almost continuous increase in the rate of acceleration of development (practically all values exceed the value of "1"), i.e., intelligence development takes place in all micro-age interval, but, to some extent, in heterochronic manner. Only one unexpected result was revealed: some decrease in results of test with spatial tasks in K11.

As an important result one can note decrease of DAl from $\mathrm{K} 9$ to $\mathrm{K} 11$ that could be explained by selective nature of mathematical schools at early stages (K7 and K8) that can lead to relatively slow improvement of indices of the intellect structure, because such student have higher level of intellect, as it was demonstrated above.

Table 1.

Components of the intellect structure and their changes in micro-age intervals in relation of next to previous ones

\begin{tabular}{|l|l|l|l|l|l|l|l|l|}
\hline $\mathrm{k} /(\mathrm{k}-1)$ & \multicolumn{1}{|c|}{ LS } & \multicolumn{1}{|c|}{ GE } & \multicolumn{1}{|c|}{ AN } & \multicolumn{1}{|c|}{ RA } & \multicolumn{1}{|c|}{ FS } & WU & ME \\
\hline $9 / 8$ & 1,07 & 1,00 & 1,33 & 1,29 & 1,15 & 1,01 & 1,12 & 1,11 \\
\hline $10 / 9$ & 1,05 & 1,04 & 0,99 & 0,99 & 1,00 & 1,05 & 1,09 & 1,05 \\
\hline $11 / 10$ & 1,08 & 1,00 & 1,06 & 1,05 & 1,02 & 0,93 & 0,96 & 1,01 \\
\hline
\end{tabular}

It is clear from the table that the highest acceleration has been demonstrated by the K9 in comparison with K8, especially in such intellect components as search for similarity and analogy, as well as mathematical calculation and revealing of regularities. Increase of the intellect components in $\mathrm{K} 10$ and K11 of the lyceum of math profile has not been revealed, in contrast with general school tendency that was found in previous research. It can be assumed that selection children with high math abilities and appropriate training in 8-th class ensure not only good math skills, but development of higher intelligence.

Conclusions and outlook

1. Individual psychological features of the transformation of the intellectual qualities' structure were revealed depending on age, profile of training.

2. It has been confirmed that the most significant changes in the level of intelligence occur in the 9th and 11th academic years, when the most significant development was demonstrated in such intellectual qualities as combinatorial thinking, the mobility of thought processes and logic.

3. The results indicated that refinement of the mechanisms of intelligence development require longitudinal studies and expansion of the base of educational institutions in order to increase the effectiveness of personality-oriented learning.

Some fruitful results in understanding of the intellect structure changes in micro-age intervals at high school could be expected in relationship of intellect personality features, namely as regards the style of thinking and features of properties of the central nervous system.

\section{References}

1. Education and Training 2020 Work programme Thematic Working Group 'Assessment of Key Competences' Literature review, Glossary and examples. European Commission, Directorate-General for Education and Culture, November, 2012. 52.

2. Veronica B. M. and Anthony W. J. Educating for Global Competence: Learning Redefined for an Interconnected World. 2013. URL: \%2OHHJ.pdf

3. Burov O. Life-Long Learning: Individual Abilities versus Environment and Means. Proc. 12th Int. Conf. ICTERI 2016, Kyiv, Ukraine, June 21-24, 2016, CEUR-WS.org. URL: http://ceur-Integration, Harmonization and Knowledge Transfer. 2016. Vol1614. P. 608-619.

4. Wu-Tien Wu. Toward A Successful Career through Personal Intelligence: A Chinese Cultural Point of View. Keynote paper presented at the 5th Asia-Pacific Conference on Giftedness, New Delhi, India, September 1-5, 1998. Also published in 2000 in K. Maitra (Ed.). Toward excellence: Developing and nurturing giftedness and talent. New Delhi, India: Mosaic Books. Pp.7388.

5. Lytvynova S. G. Formation of on-line learning environment in general education institutions. Computer u shkoli ta sim'i. 2010. № 8. Pp. 25-27.

6. Lyvynova S., Burov O. Methods, Forms and Safety of Learning in Corporate Social Networks. ICT in Education, Research and Industrial Applications. Integration, Harmonization and Knowledge Transfer. Proceedings of the 13th International Conference on ICT in Education, Research and Industrial Applications. Integration, Harmonization and Knowledge Transfer, Kyiv, Ukraine, May 15-18, 2017, pp. 406-413. URL: http://ceur-ws.org/Vol-1844/10000406.pdf

7. Smulson M. L. Psychology of intellect development: Monograph. K., 2001. 276 c.

8. Kholodnaia M. A. Psychology of intellect. SPb.: Piter, 2002. 272 p.

9. Gardner, H. Three Distinct Meanings of Intelligence. In R.J.Sternberg, J. Lautrey, \& T. Lubarty (Eds.) Models for Intelligence fort the New Millennium. Washington DC: American Psychological Association, p. 43-54.

10. Zasekina L. V. Structural and functional organization of intellect. Ostrog: Vyd-vo Nacionaljnogho universytetu «Ostrozjka akademija», 2005. $370 \mathrm{p}$.

11. Ushakov D. V. Structure and dynamics of intellectual abilities: Avtoref. dyss. d-ra psykhol. nauk. Moskwa, 2004. 42 p.

12. Grib, E.V., To the problem of correlation of social and other kinds of intelligence. Istoricheskaya i sotsial'no-obrazovatelnaya mys'I = Historical and Social Educational Idea. 2017. Vol . 9. no. 1. Part. 1. Pp. 135-138. doi: 10.17748/2075-9908-2017-9-1/1$135-138$ 
13. Burov O., Tsarik O. Educational workload and its psychophysiological impact on student organism. Work. Volume 41, Supplement 1/ 2012. Pp. 896-899.

14. Szabo, Attila. Matematikundervisning för begåvade elever - en forskningsöversikt. 2017 In: Nordisk matematikkdidaktikk, ISSN 1104-2176, Vol. 22, no 1, 21-44 p.

15. Burov O. Yu. Monitoring of Intellect Development of Math High Schools' Students. Physical and Mathematical Education : scientific journal. 2017. Issue 4(14). P. 156-160.

16. Burov O. Yu. Dynamics of development of intellectual abilities of gifted person in teenagers / O. Yu. Burov, V. V. Rybalka, N. D. Vinnyk, V. V. Rusova, M. A. Percev, I. O. Plaksenkova, M. O. Kudrjavchenko, A. B. Saghalakova, Ju. M. Chernjak; Za red. O. Ju. Burova. K. : Tov «Informacijni systemy», 2012. $258 \mathrm{~s}$.

\section{ПРОФІЛЬНЕ МАТЕМАТИЧНЕ НАВЧАННЯ: ОСОБЛИВОСТІ СТРУКТУРИ ІНТЕЛЕКТУ СТАРШОКЛАСНИКІВ Буров Олександр Юрійович}

Інститут інформаційних технологій і засобів навчання НАПН України

Анотація. У статті розглядаються питання розвитку структурних компонентів інтелекту серед учнів старших класів шкіл/класів математичного профрілю у порівнянні з учнями старшокласників у цілому (без урахування їх профільної орієнтації). Дослідження включало виконання психологічних тестів учнями на комп'ютері, а саме: модирікованого тесту структури інтелекту Р. Амтхауера, кольоро-асоційованого тесту М.Люшера (метод парних виборів), визначник типів Майерс-Бриггс. Було обстежено близько 3800 учнів 7-11 класів. Результати досліджень підтвердили дані про стійке зростання рівня розвитку інтелекту з переважним домінуванням вербального компонента у старшому юнацькому віці. у той же час аналіз окремих компонентів інтелекту вказує на гетерохронність цього процесу, з різним прискоренням у 10-11 класах. Виявлено, що такі компоненти інтелекту як пошук загальних рис, схожості та аналогії, математичні розрахунки, а також виявлення закономірностей можна пояснити впливом спеціалізованої математичної підготовки. Це було підтверджено порівняльним аналізом із середніми даними загальноосвітніх шкіл, де виявлено значні коливання у всіх складових інтелекту, а також їх нижчий рівень розвитку в цілому. Динамічні зміни інтелекту групи одних і тих же студентів у 9-му, 10-му та 11-му класах у всіх компонентах інтелекту зросли в останній рік шкільного навчання. Запропоновано показник "крефріцієнт прискорення розвитку" (КПР) для аналізу та порівняння таких змін. Аналіз КПР дозволив виявити особливості зростання компонентів інтелекту у 10 та 11 класах ліцею математичного профрілю, на відміну від загальноосвітньої тендениії, яка була виявлена в попередніх дослідженнях. Можна припустити, що підбір дітей з високими математичними здібностями та відповідне навчання у 8-му класі забезпечує не тільки належні уміння з математики, але й розвиток більш високого інтелекту. Загалом, результати досліджень чітко продемонстрували, що інтелект учнів середніх шкіл має динамічний характер на мікро-вікових інтервалах. Відмінності в його вимірі (у цьому віці) був не результатом недостатньої валідності методики, але результатом інтенсивного розвитку інтелекту, і це слід враховувати при оцінці здібностей учнів та при виборі ними майбутньої професії.

Ключові слова: інтелект, оцінювання, експериментальні дослідження, комп'ютерні засоби. 